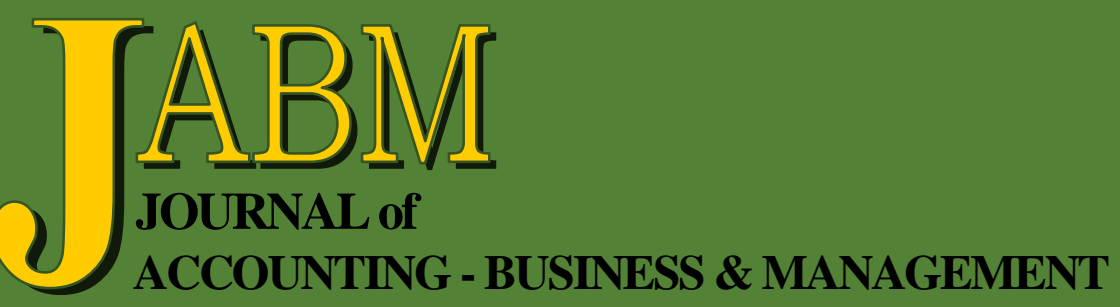

Individualism versus Collectivism Orientation as Moderator between Co-Workers' Social Support and Work to Family Enrichment

Aneel Kumar, Khalil Ahmed Channa and Muhammad Waqas Maharvi

Strategic Alliances in Knowledge-Intensive Industries: An Integrated View

Yongliang Stanley Han and Xiang Liu

Strategic Investment Decisions: An Empirical Study of Power Sector in India

Santosh Phulpagar, Koilakuntla Maddulety, Srinath Jagannathan, and Shalini Kalia

The Design of a Web-Based Program for Reporting Incomes Tax Article 21 for Civil Servants

Damayanti and Tri Sandhika Jaya

The Deceitfulness of Sticky Costs on Banking Systems

César Vela-Beltrán-del-Río and Luis Felipe Llanos Reynoso 
Journal of Accounting - Business \& Management vol. 25 no. 2 (2018) 22-49

\title{
Strategic Investment Decisions: An Empirical Study of Power Sector in India
}

\author{
Santoshkumar Phulpagar* \\ Koilakuntla Maddulety† \\ Srinath Jagannathan $\ddagger$ \\ Shalini Kalia\$
}

\begin{abstract}
Organization culture, internal resources and tools, industry, eco-techno environment and socio-political environment factors are combined to build a model to evaluate their impact on the effectiveness of strategic investment decisions. Empirical data collected from decisions makers in the Indian power sector was used for the study, and it was observed that all latent factors have a positive effect on the effectiveness of investment decisions at 90\% confidence level. Though the internal resources and tools and socio-political environment do not have a positive impact on the effectiveness of investment decisions at $95 \%$ confidence level based on interaction effects, it may be argued that the socio-political environment strengthens a positive relationship between internal resources and tools; and the effectiveness of strategic investment decisions. There is no significant difference except for the effect of socio-political environment factors and internal resources and tools.
\end{abstract}

Keywords: strategic investment decisions, power sector, organizational factors, industry factors, economy drivers.

\section{INTRODUCTION}

All organizations make strategic decisions for their survival and future growth. Several studies have attempted to understand the factors that influence the effectiveness of such decisions (Phulpagar \& Maddulety, 2011). These decisions may be driven by internal changes or in response to external forces (Asrilhant et al., 2004; Srinivasan, 2009). This paper seeks to understand the factors that influence strategic investment decisions, with a focus on the power sector in India.

In the current context of the regular restructuring of businesses and people in response to opportunities and challenges in the external environment, research on the topic of identification and selection of corporate strategies becomes useful (Porter, 1987; Hamel \& Prahalad, 1994). Uncertainty plays an important role in the selection of strategic decisions (Amram \& Kulatilaka, 1999). For strategic investment decisions, one

\footnotetext{
* Head - TA, L\&D (Learning and Development), CG Power and Industrial Solutions Limited, Kanjur Marg (E) Mumbai 400042, India. Phone: +91 0226755 9205. Mobile phone: +91 8879181885. E-mail: santosh.phulpagar@cgglobal.com and santosh.phulpagar@gmail.com.

† Deputy Director (Research), S. P. Jain School of Global Management, Kurla Campus, Mumbai, India. $1^{\text {st }}$ Floor, Kohinoor City Mall, Premier Rd, Kurla, Mumbai 400070, India. E-mail: k.maddulety@spjain.org.

¥ Asst. Professor, Indian Institute of Management Indore, India. Prabandh Shikhar, RauPithampur Road, Indore - 453556, Madhya Pradesh, India. E-mail: srinathj@iimidr.ac.in.

$\checkmark$ Associate Professor, S. P. Jain School of Global Management, Kurla Campus, Mumbai, India. 1st Floor, Kohinoor City Mall, Premier Rd, Kurla, Mumbai 400070, India. E-mail: shalini.kalia@spjain.org.
} 
needs to consider both financial perspectives as well as non-financial parameters. The traditional quantitative cost-benefit analysis is no longer sufficient for addressing the complexity of investment decisions (Phulpagar \& Maddulety, 2013; Mohanty \& Mohanty, 2014). Strategic decisions are normally taken in alignment with the mission and vision of the organization. In case of power sector firms, due to sustainability and social cost, despite higher investment requirements investment decisions tend to favour renewable power such as, wind power, in contrast to traditional sources of power (Merriman \& Sen, 2012; Silva de Souza et al., 2013; and Attig et al., 2014).

The investment requirement in the global energy sector would be half of current world GDP over the next two decades to address emerging challenges and build strong energy infrastructure. The power sector alone would need sizable investment from this pie of energy sector. Per capita power consumption is on the rise in countries like India due to growth in industrial demand and population, coupled with the rising aspirations of people to own more luxury items such as electronics appliances. The challenge in the coming days would be to develop smart ways of consuming power. India is the third largest producer of electricity in the world. The growth of the electricity sector in India is likely to provide a sustainable alternative to the traditional burning of fossil fuels, especially in rural areas. Ensuring reliable generation and supply of electricity is a necessary condition to address India's problems of water pollution and associated environmental issues (e.g., sewage treatment plants). The power sector has been selected for this study given the significance of the sector in the current scenario.

This paper makes three contributions. First, this study has developed a framework based on five components for ascertaining the effectiveness of strategic investment decisions in the power sector. The proposed model has been validated based on empirical data. Second, this study provides inter-relationships of the components of strategic investment decisions. Third, practising managers can use these components to identify the pros and cons of their investment decisions.

In the following sections, a theoretical framework for strategic investment decision making is built based on the theories related to investment strategy, organization behavior and organization's external environment. This framework contributes to strategic management literature by indicating how organizations from the power sector could consider investment decisions through an analysis of internal and external factors. The theory related to how these internal and external factors influence the effectiveness of investment decisions is also specified. We proceed to specify how the interaction effects of the internal and external factors impact the outcome of investment decisions.

Two studies were carried out, the first being a pilot study to define and calibrate the scale for assessing the impact of internal and external factors on the effectiveness of investment decisions, and the second being a detailed study to get the perceptions of power industry executives to test the proposed models. The models were also tested by choosing the control variable related to the decision maker's characteristics, mainly their position in the hierarchy.

\section{THEORETICAL FRAMEWORK AND HYPOTHESIS DEVELOPMENT}

Three factors influence the effectiveness of strategic investment decisions. These factors are internal to the organization, related to the industry of the organization and linked to the overall economy. The investment decisions are primarily driven by internal and external factors in any organization ( $\mathrm{Lu} \&$ Heard, 1995). Internal factors are not only products, functions, processes and finances, but also intangibles such as 
culture, people, and leadership depth. External factors include complex collection of forces (such as economic, political, social and technological), actors (customers, suppliers and regulators) and behaviors (consumer and competitor) (Adcroft et al., 2008). Even these three factors have greater influence over each other. The internal factors of an organization shape the industry factors. Similarly, industry factors shape the economic factors, it could be other way too. The focus of this study is to understand the inter-relationship of these factors and their impact on the effectiveness of the strategic investment decisions. The conceptual framework is shown in Figure 1.

Figure 1

\section{Conceptual Framework}

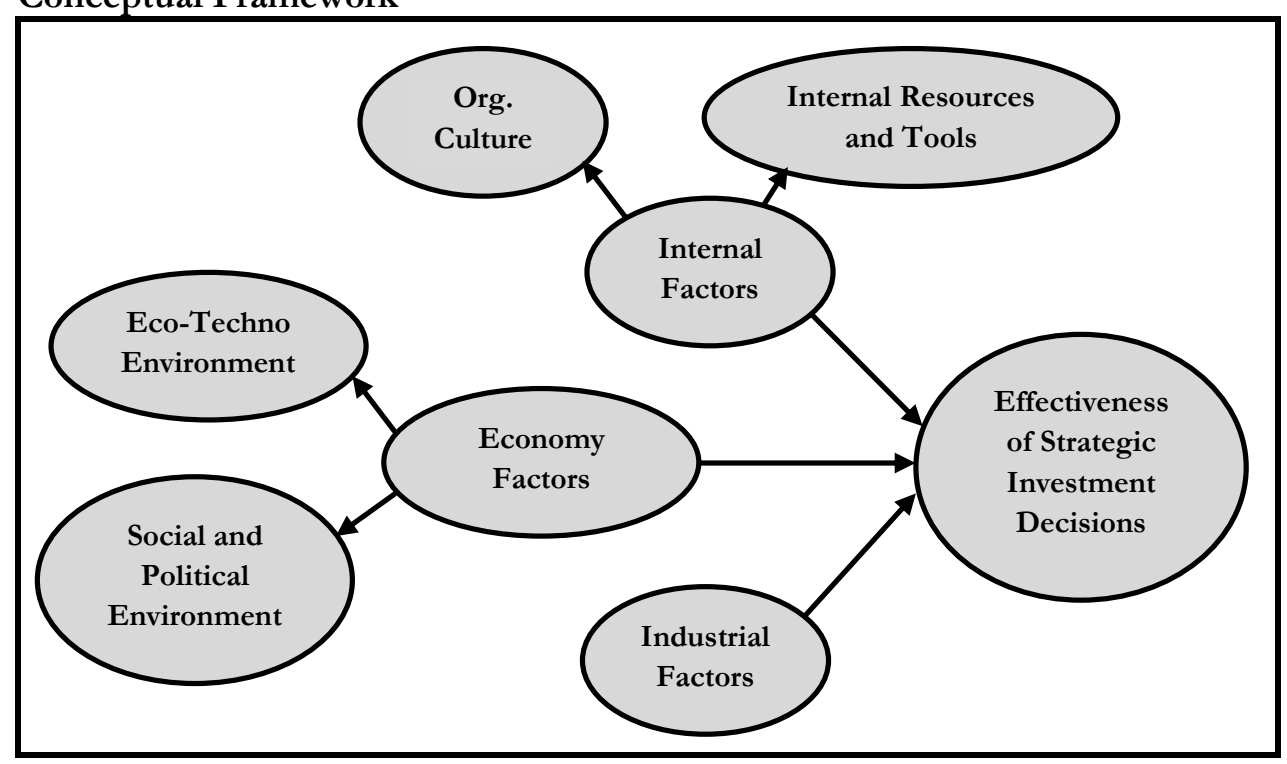

Though the focus of this study was on the Indian power sector, power scenario in other countries was also studied to understand the global perspective. As per Wright et al. (2010), Cuban power sector would need heavy investment to meet the rise in demand. Cuba, as a nation, had been isolated from the global economy and was largely dependent on external support, especially for subsidized oil. The existing power plants were ageing and were using expensive fuels for power generation. The factors that influenced the investment decisions were cost-benefit analysis of different options such as, capital versus operating cost, the availability of raw material such as, coal, etc., demand pattern, availability of funds and environmental considerations.

Lu and Heard (1995) examined and compared strategic investments in Chinese and British firms. Firms in both the countries displayed similar bureaucratic styles. British managers appeared to enjoy more autonomy compared to their counterparts in China. Profitability was important for British firms whereas social obligations or individual career aspirations were more important for Chinese managers. Their study concluded that strategic investment decision-making is dependent upon problemsolving processes, resources availability, internal and external environments, communication channels within and outside the organization.

\subsection{Hypothesis Development}

This study proposes a model to show the impact of internal factors (organization culture and internal resources and tools), industry factors and economy factors (ecotechno environment and socio-politico environment) on the effectiveness of strategic 
investment decisions in the power sector (Rusjan, 2005; Elbanna et al., 2015; and Lai et al., 2015). Business performance is a reflection of the effectiveness of strategic decisions, whether to invest, defer or abandon projects (Vickery, 1991; Rusjan, 2005). Selection of the right investment project is the key for an organization to create value and survive (Chou et al., 2007). Economic factors drive the industry related decisions taken by policymakers. Industry decisions, in turn, drive the internal factors of a firm.

\subsection{Effect of Organization Culture on Strategic Investment Decisions}

Organization culture provides an overview of the identity of the organization in terms of people practices, the collective behavior of the leadership team, business processes, quality of infrastructure etc. (Pratt \& Foreman, 2000; Corley, 2004; and Andersen \& Jonsson, 2006). The way people are organized has become an important strategic variable (Daft \& Lewin, 1993; Baligh et al., 1996; and Williams \& Rains, 2007). Andrews (2010) suggested that the social capital within organizations is a powerful resource for taking, and subsequently ensuring, the effectiveness of strategic decisions.

Elbanna et al. (2015) showed that multiple factors simultaneously contribute to determining the quality of decision implementation. These factors are related to firm characteristics such as performance; team culture such as the degree of trust and collaboration; and implementation drive such as speed and clarity in implementation decisions. Drummond (2014) argued that a strategic decision is considered a failure when experience consistently suggests that important expectations would not be met. The main drivers for failure could be overconfidence, sunk costs, the perceived need for self-justification, denial, social costs of admitting failure, completion effects, and exit barriers/organizational entrenchment. Therefore:

Hypothesis 1: organization culture positively influences the effectiveness of strategic investment decisions.

\subsection{Effect of Internal Resources and Tools on Strategic Investment Decisions}

Internal resources - in terms of human resources, ability to raise funds, physical assets provide direction to strategic decision making and in determining its effectiveness (Collis, 1991; Lee \& Miller, 1999; and Peng, 2001). Organizational capabilities such as production competence, integrated systems, engaged employees etc., positively influence business performance and are dependent on the activities performed by the organization. A firm can improve the effectiveness of strategic decisions by working on different strategic decision dimensions such as human resource management, supply chain management, technology improvement, quality assurance system etc. (Bae \& Lawler, 2000; Carpenter et al., 2001).

The role of analysis based on decision tools needs to be recognized for ensuring effective decision making, instead of pulling out popular and universal techniques based on benchmarking (Kogut \& Kulatilaka, 1994; Pandza et al., 2003; Shil \& Allada, 2007; and Jackson, 2010). Decision tools are widely recognized in accelerating the effectiveness of strategic investment decisions. In an uncertain environment, the use of real options (RO) is considered more appropriate than tools such as net present value (NPV) or internal rate of return (IRR) (Krychowski \& Quélin, 2010). Decision makers need to understand the implications of inappropriate escalation of commitment to help them in allocating resources effectively (Greer \& Stephens, 2001).

For taking the right strategic decisions, a firm needs to be market-oriented (Narver \& Slater, 1990; Jaworski \& Kohli, 1993; and Hult \& Ketchen, 2001). Market orientation determines how closely an organization is listening to the market needs and responding to them. Therefore: 
Hypothesis 2: internal resources and tools positively influence the effectiveness of strategic investment decisions.

\subsection{Effect of Industry Factors on Strategic Investment Decisions}

The global power demand is expected to double by 2050 due to population growth, economic growth, improved quality of life and increased urbanization (Eisenhardt \& Schoonhoven, 1990; Klepper, 1997; and Rosenbusch et al., 2013). Posner (1993) noticed that sustainable competitive advantage depends on shifting from coal-based technologies to newer technologies such as nuclear power and natural gas. Government policies have always influenced the composition of the power sector industry, based on the raw material and technology used for power generation (Schneider et al., 2010). Industry factors that traditionally played an important role in strategic decisions in the power sector are resources supply, technical characteristics of existing and future power plants, operational costs, demand potential, cost of funding, etc. (Wright et al., 2010).

Hall and Lundberg (2010) tested a hypothesis that firms in high velocity, dynamic and fast-changing environments are more likely to develop good competitive knowledge and intelligence systems to assist decision-makers in making better-informed decisions. Investing in the capacity of flexible resources meant to meet the needs of a wide envelope of products is a common business strategy for firms operating in environments with substantial demand and product mix uncertainty (Kouvelis \& Tian, 2014). Therefore:

Hypothesis 3: industry factors positively influence the effectiveness of strategic investment decisions.

\subsection{Effect of Eco-Techno Environment on Strategic Investment Decisions}

Several environmental conditions promote technological pioneering that is, technological innovations for competitive advantages. For instance, when the rate of technological diffusion in the industry is low, pioneering is advantageous. Slow diffusion occurs because of the prohibitive cost of imitation by competitors, especially when the technology embodies rare or unique skills, making it impossible to copy (Zahra et al., 1995). Kang (2005) presented a technology-centred strategic planning model, which emphasized the important role of technology in strategy formulation and implementation of services. Technological forces influence decision choices for the leadership team (Kozloff, 1994; Schneider et al., 2010).

Economic forces such as the cost of capital, currency rates, trade barriers/ enablers, tax rates, etc., play an important role in strategic decisions. For example, Euro currency fluctuations arising out of economic forces influenced strategic decisions in EU countries (Jager, 2013). Therefore:

Hypothesis 4: eco-techno environment positively influences the effectiveness of strategic investment decisions.

\subsection{Effect of Socio-Politico Environment on Strategic Investment Decisions}

Political-legal forces have a significant effect on the demand and supply situation in the power sector. Chen et al., (2010) analyzed the impact of political-legal forces on the growth of the power sector in China. Social-cultural forces influence the decisionmaking process in an organization (Hofstede, 1980; Schneider \& Barsoux, 1997). Sociocultural forces also influence the assessment of who can be considered an effective leader and the determinants of effective leadership behavior (Elenkov \& Manev, 2005). Therefore: 
Hypothesis 5: socio-politico environment positively influences the effectiveness of strategic investment decisions.

\subsection{Interaction Effect of Organization Culture, and Internal Resources and Tools on Strategic Investment Decisions}

Organization culture and internal resources and tools have a positive effect on the effectiveness of strategic investment decisions (Rusjan, 2005). Based on the theory of interaction effect, it was decided to evaluate the interaction effect of organization culture and internal resources; and tools on the effectiveness of strategic investment decisions.

Miller (1986) had proposed two ways of studying an organization, based on his thorough review of the literature on the subject of strategy and structure. One way would be to select one or two dimensions of strategy at a time (e.g., directions related to cost, quality, revenue, innovation, etc.) and relate them to the individual, organizational variables (centralization $\mathrm{v} / \mathrm{s}$ decentralization etc.). The other way is to recognize the inter-linkages of the structural elements and use this as a common configuration. These common configurations are then related to the particular strategic, structural and environmental configurations. He recommended the use of the second type for a better understanding of the relationship between strategy and structure. Therefore:

Hypothesis 6: organization culture positively influences the internal resources and tools.

Hypothesis 6a: organization culture and internal resources and tools have a positive interaction effect on the effectiveness of strategic investment decisions.

\subsection{Interaction Effect of Industry Factors and Organization Culture on Strategic Investment Decisions}

Well planned technological innovations which are strongly supported by the right structure and an effective marketing plan can help an organization to achieve a market leadership position. Commercialization of new technology is possible only if there is synergy among teams from production, marketing, $\mathrm{R}$ and $\mathrm{D}$ and other divisions. The synergy helps to understand technical and market issues and resolves them speedily (Zahra et al., 1995). Decision-makers need to understand the market requirements and their expectations of the organizational culture to be successful in the market. (Deshpande \& Webster, 1989).

Scherer (1970) highlighted that a company's strategic options are driven, based on environmental conditions. This approach is known as structure-conductperformance and has been one of the schools of thought in the area of strategy. Accordingly, firm performance in terms of resource allocation towards right decisions is driven mainly by basic structural factors such as customers, competitors, suppliers, entry barriers etc. The other school of thought led by Kim and Mauborgne (2004) observed and propagated that a firm's strategies shape industry structure. They proposed a theory known as "blue ocean strategy" which suggested that firms can systematically reconstruct the industry structure and reverse the structure-strategy sequence direction in their favor. Therefore:

Hypothesis 7: the industry factors positively influence organizational culture.

Hypothesis 7a: the industry factors and organizational culture have a positive interaction effect on the effectiveness of strategic investment decisions. 


\subsection{Interaction Effect of Industry Factors, and Internal Resources and Tools on Strategic Investment Decisions}

A firm's external environment (comprising competitors, customers, suppliers, technology and government regulations) influences the allocation of organizational resources (Chmielewski, 2010). Effective allocation of resources demands that decision-makers recognize and take action on further investment or liquidate an investment (Greer \& Stephens, 2001).

The way organizations manage time can be a differentiating resource and is likely to become a source of competitive advantage and survival (Shi \& Prescott, 2008). As time is a scarce, valuable and non-imitable resource (Carlstein, 1982), how firms manage time in the planning and execution of strategic investment-related initiatives can become a critical issue.

Kim and Mauborgne (2009) reconciled theories around the sequence of strategy and structure and mentioned that the sequence of structure and strategy depended upon three factors - the structural conditions, resources and capabilities, and the strategic mindset of an organization. Therefore:

Hypothesis 8: the industry factors positively influence internal resources and tools.

Hypothesis 8a: the industry factors and internal resources and tools have a positive interaction effect on the effectiveness of strategic investment decisions.

\subsection{Interaction Effect of Eco-Techno Environment and Industry Factors on Strategic Investment Decisions}

Wulandari (2014) argued that economic and technological factors influence the industry structure, with the help of the example of digital publishing industry. He developed and analyzed hypothesis related to the piracy effect on digital publishing industry due to economic and technological factors. Since price drives buying decisions, the industry structure gets affected due to the consideration of profit and loss (Glass \& Wood, 1996). If the same value is received by different modes or channels of product/service distribution, consumers are likely to prefer the one with a lower price. Better connectivity coupled with easier access helped in the e-commerce revolution. Economic forces acting in the external environment influence labor and raw material supply (Hampson, 2012).

Lin and Yang (2013), while analyzing the energy efficiency issues for the Chinese market, observed that economic policies drive the structure of the power industry in China. In China, $80 \%$ of power is generated through coal-based power plants. This is primarily due to the abundance and low cost of coal in China. However, under the background of energy conservation, emission reduction, and low carbon development, energy resource is becoming an important development bottleneck. Based on the need to change the mode of economic growth, it was noted that the structure of the power industry is changing through economic and technological developments, especially in favor of renewable sources of energy. Therefore:

Hypothesis 9: the eco-techno environment positively influences industry factors.

Hypothesis 9a: the eco-techno environment and industry factors have a positive interaction effect on the effectiveness of strategic investment decisions. 


\subsection{Interaction Effect of Socio-Politico Environment and Industry Factors on Strategic Investment Decisions}

Shi, Sun, and Prescott (2012) studied recent works in sociology and provided theoretical underpinnings of why sequence matters and how interdependence between different sequences occurred. They concluded that certain sequences were more likely to generate higher performance than others. However, such a relationship was found to be largely contingent on the firms' developmental stages.

The social and environmental impact is assessed before taking any key strategic investment decision as this might turn out to be a big obstacle subsequent to huge investment commitment (Domínguez-Gómez, 2016). There are industry-specific guidelines for assessing the social and environmental impact and its compliance. Political atmosphere influences the guidelines designed in this regard to a great extent. It is considered to be a key component of risk assessment and management for a firm (Dendena \& Corsi, 2015). Thus socio-politico environment has a significant impact on industry structure. Therefore:

Hypothesis 10: the socio-politico environment positively influences industry factors.

Hypothesis 10a: the socio-politico environment and industry factors have a positive interaction effect on the effectiveness of strategic investment decisions.

\subsection{Interaction Effect of Eco-Techno Environment and Socio-Politico Environment on Strategic Investment Decisions}

Almfraji and Almsafir (2014) reviewed the literature from 1994 to 2012, examining the relationship between foreign direct investment and economic growth across the globe. They noticed that the economy and technological factors have an impact on the socio-political environment in a country. Huyen (2015) made similar observations about Vietnam.

Pheng and Chuan (2006) reviewed factors critical to the success of a project. It was observed that apart from factors such as, clarity on goals, project manager's competence, organization philosophy, management support, clarity on roles and responsibilities, proper allocation of resources, proper information flow mechanism, factors external to the organization such as, social, political, legal, economic and technological determined the success of projects. Therefore:

Hypothesis 11: the eco-techno environment positively influences the socio-politico environment.

Hypothesis 11a: the socio-politico environment and eco-techno environment have a positive interaction effect on the effectiveness of strategic investment decisions.

\subsection{Interaction Effect of The Economy and Internal Factors on Strategic Investment Decisions}

Organizational culture can be considered a repository of accumulated learning and experience (Nicholls, 1984). Economic and technological factors related to the industry also influence this culture. One also needs to see whether experience helped in learning the correct lessons and their relevance in changing contexts. A firm's culture significantly affects the thinking and behavior of the decision maker. Changes in the economy, political-legal, technological and social environments provide examples for the decision makers to benchmark some of the dimensions of the decision making.

Organization culture and internal resources get significantly influenced by economic factors as the external environment shapes the industry and socio-political 
pattern in any nation. The decision makers need to show flexibility and adaptability in a dynamic environment. However, one needs to be careful and use some timeless principles and universal lessons, despite changes occurring in the environment. Some experiences will remain valid even in changed conditions. Lessons learnt from experience would still provide greater value. One should understand how to differentiate between what is relevant and what is irrelevant. It is also about striking the balance of flexibility with stability, responsiveness to continuity, and the new with the old (Nicholls, 1984; Vargas, 2014). Therefore:

Hypothesis 12: the eco-techno environment positively influences the organizational culture of a firm.

Hypothesis 13: the eco-techno environment positively influences the internal resources and tools of a firm.

Hypothesis 14: the socio-political environment positively influences the organizational culture of a firm.

Hypothesis 12a: the organizational culture and eco-techno environment have a positive interaction effect on the effectiveness of strategic investment decisions.

Hypothesis 13a: the internal resources and tools, and eco-techno environment have a positive interaction effect on the effectiveness of strategic investment decisions.

Hypothesis 13b: the internal resources and tools, and the socio-political environment have a positive interaction effect on the effectiveness of strategic investment decisions.

Hypothesis 14a: the organizational culture and socio-political environment have a positive interaction effect on the effectiveness of strategic investment decisions.

The proposed model reflecting these relationships are shown in Figure 2 below:

Figure 2

Proposed Model for Strategic Investment Decisions

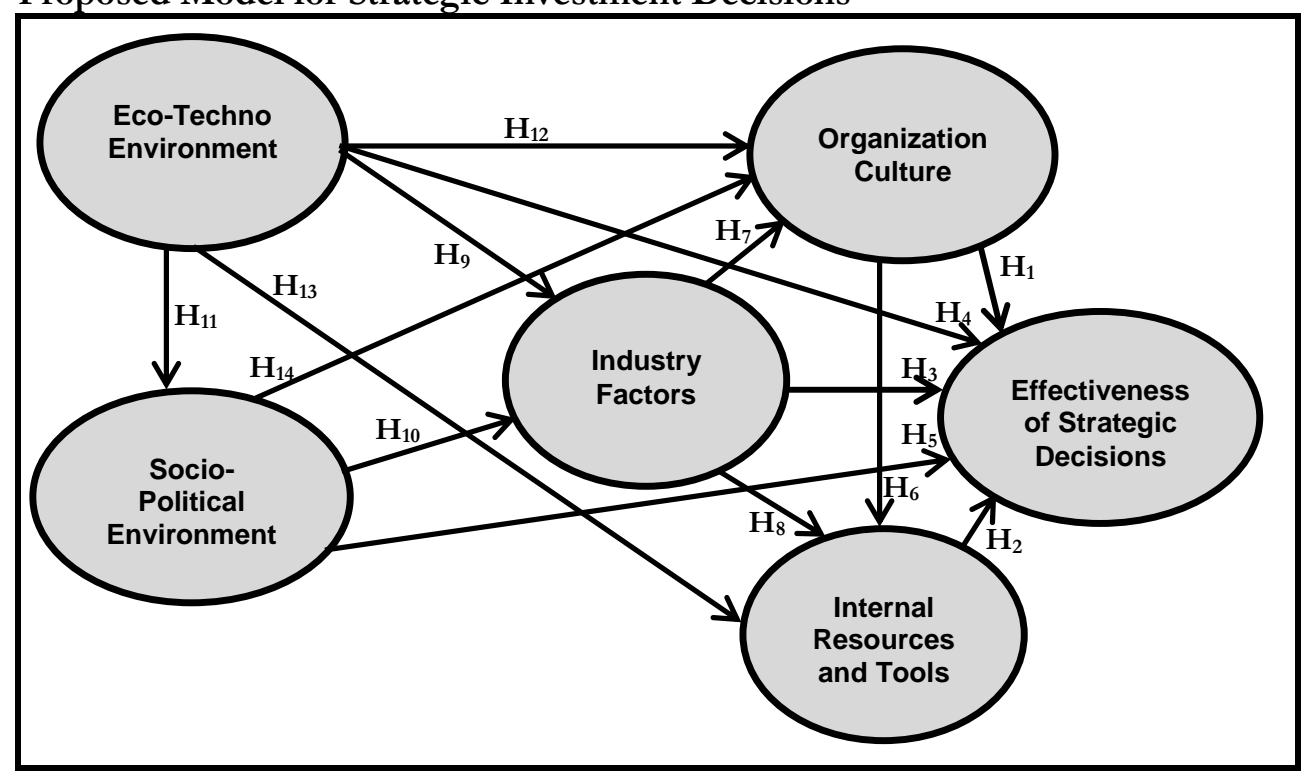




\section{RESEARCH DESIGN}

The research design is a fundamental strategy for empirical research. The objective of research design is to gather crucial data to be analyzed for developing models for effective strategic decisions (Sekaran, 2003). Since measures of the effectiveness of strategic decision making were usually applied at the level of individual leaders who take strategic decisions in an organization, the unit of analysis for this study is the individual decision maker.

\subsection{Development of Questionnaire and Research Instrument}

After analyzing literature and considering the critical background of the study, scales were developed for each of the components of investment decisions and also for the effectiveness of the investment decisions. Semi-structured interviews were conducted with ten experts having vast experience in the area of corporate strategic decision making in the power sector, to check the face validity of the items developed. The theoretical definition of all six constructs is provided in Table 1. The survey questionnaire was pre-tested and validated by a pilot study (scale refinement).

Insert Table 1 here.

\subsection{Sampling Procedure and Data Collection}

The target population included decision-makers from Indian power organizations. The reason for selecting a single industry for this study was to control extraneous variation of the cross-industry interface through the homogeneity of respondents. Though it is agreed that single industry study would limit generalizations of the research findings, single industry studies are recommended to avoid unobserved heterogeneity and also have more systematic and unbiased comparisons (Vorhies et al., 2009). The respondents who were familiar with strategic decision options and the factors influencing them were identified. This survey research was conducted in two phases in Indian power sector organizations during six months from April 2014 to September 2014. Data was collected through an online web platform as well as through personal interface. The pilot phase covered seven companies from private and public sectors. The initial study had 64 items for six factors. For scale purification, total 100 responses were gathered, which were used to assess the initial reliability and to conduct exploratory factor analysis (EFA). EFA helped in identifying the appropriate items and also to reduce the length of the questionnaire. Based on scale purification results, 28 items were retained. These statistical findings were discussed with experts from the power sector, and it was concluded that many of the dropped items had a similar meaning in the minds of respondents as some of the retained items.

Following the pilot study and scale purification, the survey questionnaire containing 28 items was finalized, along with a covering letter describing the purpose and procedure of the study, assurance of respondent anonymity and a request to comment if any questions were found unclear or difficult, apart from the option of providing suggestions for improving the design of the questionnaire. Further, for validation of a 6 -factor 28 -item scale, decision-makers from five leading public sector companies and seven private sector power companies were approached to get responses. A total of 395 responses were gathered, out of which 357 were found to be usable. Confirmatory factor analysis (CFA) was carried out for the data of 357 responses to validate the scales. The scale validation was tested by carrying out convergent and discriminant validity analysis. Further, four items were dropped to achieve an acceptable level of model fitness measures (Fornell \& Larcker, 1981). CFA results indicated scale validity. 
Table 1

Theoretical and Operational Definition of the Construct(s)

\begin{tabular}{|c|c|c|c|c|}
\hline No. & $\begin{array}{c}\text { Aggregated } \\
\text { Constructs }\end{array}$ & References & $\begin{array}{l}\text { Theoretical } \\
\text { Definition }\end{array}$ & $\begin{array}{c}\text { Operational } \\
\text { Definition }\end{array}$ \\
\hline 1. & $\begin{array}{l}\text { Organization } \\
\text { Culture }\end{array}$ & $\begin{array}{l}\text { Daft and Lewin } \\
\text { (1993); Jaworski } \\
\text { and Kohli } \\
\text { (1993); Baligh et } \\
\text { al. (1996); Pratt } \\
\text { and Foreman } \\
\text { (2000); Hult and } \\
\text { Ket-chen (2001); } \\
\text { Cor-ley (2004); } \\
\text { Wil-liams and } \\
\text { Rains (2007) }\end{array}$ & $\begin{array}{l}\text { Represents the col- } \\
\text { lective behavior of } \\
\text { the leadership team. } \\
\text { Takes the form of } \\
\text { how the team is } \\
\text { structured, the kind } \\
\text { of collaboration bet- } \\
\text { ween departments as } \\
\text { well as different le- } \\
\text { aders. It also encom- } \\
\text { passes the response } \\
\text { to changes and how } \\
\text { the organization is } \\
\text { oriented to gather } \\
\text { market intelligence. }\end{array}$ & $\begin{array}{l}\text { - Formal and informal } \\
\text { relationships of people. } \\
\text { - No. of layers within an } \\
\text { organization. } \\
\text { - Centralized v/s. decen- } \\
\text { tralized. } \\
\text { - Collective behavior of } \\
\text { employees. } \\
\text { - Nature of the relation- } \\
\text { ship. } \\
\text { - Spoken and unspoken } \\
\text { values, norms and } \\
\text { systems. }\end{array}$ \\
\hline 2. & $\begin{array}{l}\text { Internal } \\
\text { Resources } \\
\text { and Tools }\end{array}$ & $\begin{array}{lr}\text { Collis } & (1991) ; \\
\text { Carpenter } & \text { et al. } \\
\text { (2001); } \quad \text { Peng } \\
\text { (2001); Shil and } \\
\text { Allada } & \text { (2007); } \\
\text { and } & \text { Jackson } \\
(2010) & \end{array}$ & $\begin{array}{l}\text { Organizational reso- } \\
\text { urces such as depth } \\
\text { of top talent mana- } \\
\text { gement, capabilities, } \\
\text { financial leverage, } \\
\text { physical assets etc. } \\
\text { Qualitative and } \\
\text { quan-titative tools } \\
\text { used by leaders for } \\
\text { strategic decision } \\
\text { making. }\end{array}$ & $\begin{array}{l}\text { - People. } \\
\text { - Capabilities. } \\
\text { - Financial resources. } \\
\text { - Physical assets. } \\
\text { - IT systems. } \\
\text { - Decision tools such as: } \\
\text { ○ Real options. } \\
\text { ○ Game theory. } \\
\text { ○ AHP. } \\
\text { ○ Decision tree. } \\
\text { NPV, IRR, etc. }\end{array}$ \\
\hline 3. & $\begin{array}{l}\text { Industry } \\
\text { Factor }\end{array}$ & $\begin{array}{l}\text { Posner (1993); } \\
\text { Klepper (1997); } \\
\text { Hall and Lund- } \\
\text { berg (2010); and } \\
\text { Rosenbusch et } \\
\begin{array}{l}\text { al. (2013) }\end{array}\end{array}$ & $\begin{array}{l}\text { Dimensions of cus- } \\
\text { tomers in terms of } \\
\text { demand patterns, so- } \\
\text { urces of supply, } \\
\text { types of products } \\
\text { and ser-vices, } \\
\text { pricing, dis-tribution } \\
\text { channels etc. It also } \\
\text { represents the } \\
\text { general principles by } \\
\text { which a govern-ment } \\
\text { is guided in its } \\
\text { management of pu- } \\
\text { blic affairs or rules } \\
\text { of law for the } \\
\text { industry. }\end{array}$ & $\begin{array}{l}\text { - A mix of power ge- } \\
\text { neration sources such as } \\
\text { thermal, renewable, nu- } \\
\text { clear, hydro, etc. } \\
\text { - Demand and industry } \\
\text { growth pattern. } \\
\text { - Customer behavior. } \\
\text { - Relationship of market } \\
\text { players. } \\
\text { - A government plan to } \\
\text { create the power related } \\
\text { infrastructure. } \\
\text { - Government's preferen- } \\
\text { ce for the import/export } \\
\text { of product/services. } \\
\text { - Raw material and other } \\
\text { resources availability. }\end{array}$ \\
\hline
\end{tabular}


To be continued Table 1.

\begin{tabular}{|c|c|c|c|c|}
\hline No. & $\begin{array}{c}\text { Aggregated } \\
\text { Constructs }\end{array}$ & References & $\begin{array}{l}\text { Theoretical } \\
\text { Definition }\end{array}$ & $\begin{array}{c}\text { Operational } \\
\text { Definition }\end{array}$ \\
\hline 4. & $\begin{array}{l}\text { Eco-Techno } \\
\text { Environment }\end{array}$ & $\begin{array}{lr}\text { Zahra et al. } \\
(1995) ; & \text { Kang } \\
(2005) ; & \text { Schne- } \\
\text { ider et al. } \\
(2010) ; & \text { and } \\
\text { Hampson } & \\
(2012) & \end{array}$ & $\begin{array}{l}\text { Evolution in tech- } \\
\text { nology that shapes } \\
\text { the overall econo- } \\
\text { my. Factors such as } \\
\text { employment level, } \\
\text { inflation rate, inte- } \\
\text { rest rate, demogra- } \\
\text { phic changes, and } \\
\text { fiscal and moneta- } \\
\text { ry policies that de- } \\
\text { termine the state of } \\
\text { the competitive en- } \\
\text { vironment in which } \\
\text { a firm operates. }\end{array}$ & $\begin{array}{l}\text { - Economic forces deter- } \\
\text { mine the output of a firm } \\
\text { marketing activities. } \\
\text { - Investment appetite. } \\
\text { - Level of capital flow. } \\
\text { - Labour laws are affect- } \\
\text { ing the economic acti- } \\
\text { vities. } \\
\text { - The impact of techno- } \\
\text { logical changes on } \\
\text { the overall economy. } \\
\text { - Innovative culture. } \\
\text { - Market forces. }\end{array}$ \\
\hline 5. & $\begin{array}{l}\text { Socio-Politi- } \\
\text { co Environ- } \\
\text { ment }\end{array}$ & $\begin{array}{l}\text { Hofstede } \\
(1980) ; \text { Elenkov } \\
\text { and Manev } \\
\text { (2005); Chen et } \\
\text { al. (2010); and } \\
\text { Jager (2013) }\end{array}$ & $\begin{array}{l}\text { The overall struc- } \\
\text { ture of political ac- } \\
\text { tivities and legal } \\
\text { conditions. The so- } \\
\text { cietal conditions } \\
\text { that determine the } \\
\text { level of long-term } \\
\text { orientation, auto- } \\
\text { nomy, egalitarian- } \\
\text { ism, individualism } \\
\text { etc. }\end{array}$ & $\begin{array}{l}\text { - Level of generally ac- } \\
\text { cepted behavior in } \\
\text { the society. } \\
\text { - Societal peer pressure. } \\
\text { - Political activities deter- } \\
\text { mine the path of eco- } \\
\text { nomic growth. } \\
\text { - Political activities deter- } \\
\text { mine which sector would } \\
\text { grow. } \\
\text { - Legal conditions deter- } \\
\text { mine the environment in } \\
\text { which industries operate. }\end{array}$ \\
\hline 6. & $\begin{array}{l}\text { The effective- } \\
\text { ness of Stra- } \\
\text { tegic Invest- } \\
\text { ment Decisi- } \\
\text { on Making }\end{array}$ & $\begin{array}{lr}\text { Porter } & (1987) ; \\
\text { Lu and } & \text { Heard } \\
(1995) ; \quad \text { and } \\
\text { Merino } & \text { and } \\
\text { Rodríguez } & \\
(1997) & \end{array}$ & $\begin{array}{l}\text { The degree of suc- } \\
\text { cess of strategic de- } \\
\text { cisions. Strategic } \\
\text { investment decisi- } \\
\text { ons are those that } \\
\text { affect the long- } \\
\text { term performance } \\
\text { of the business and } \\
\text { that relate directly } \\
\text { to its aims and } \\
\text { objectives. }\end{array}$ & $\begin{array}{l}\text { - The most important de- } \\
\text { cisions that leaders have } \\
\text { to make. Poor decisions } \\
\text { may prove disastrous and } \\
\text { lead to the collapse of } \\
\text { the organizations. } \\
\text { - Investment decisions are } \\
\text { made on the basis of } \\
\text { critical financial, techno- } \\
\text { logical and human } \\
\text { resources required. } \\
\text { - Strategic investment de- } \\
\text { cisions emerge from on- } \\
\text { going business activities } \\
\text { and market forces. } \\
\text { - Strategic decisions invol- } \\
\text { ve a change of a major } \\
\text { kind since an organiza- } \\
\text { tion operates in an ever- } \\
\text { changing environment. } \\
\text { - Effective resource allo- } \\
\text { cation. }\end{array}$ \\
\hline
\end{tabular}




\subsection{Measurement of Variables}

More rigorous test with common method bias was used to test potential biases in the cross-sectional research design. Results of the common method bias showed that the total extraction was less than $50 \%$. The common method bias using a common latent factor was also tested. The variance obtained was within an acceptable level of CMV. Hence, the data collected was found to be unbiased.

\subsection{Convergent Validity}

Convergent validity is the extent to which an item correlates highly with other items designed to measure the same construct (Churchill, 1979). To assess the convergent validity, the following three criteria are adopted:

1) The high factor loadings of measures to the same construct when using factor analysis with 0.40 as the threshold (DeVellis, 2003)

2) The high composite reliability of the measures $(>0.60)$ as the threshold (Bagozzi \& Yi, 1988)

3) $\mathrm{CR}>\mathrm{AVE}$ (average variance extracted), AVE $>0.5$ (Fornell \& Larcker, 1981).

Table 2 shows that the composite reliabilities (CR) lay between 0.767 and 0.916 , which are $>0.60$ (Bagozzi \& Yi, 1988). The CR values had been more than AVE whose values are more than 0.5. Please refer Annexure 5 for the factor loadings of items for each of construct which is greater than the threshold (>0.40) (DeVellis, 2003). Hence the convergent validity of the developed scale is established.

Table 2

Data for Testing Convergent Validity

\begin{tabular}{clcc}
\hline No. & \multicolumn{1}{c}{ Construct } & $\begin{array}{c}\text { Composite } \\
\text { Reliability }\end{array}$ & $\begin{array}{c}\text { Average } \\
\text { Variance Extracted }\end{array}$ \\
\hline 1. & Organization Culture Factors & 0.851 & 0.663 \\
2. & Internal Resources and Tools Factors & 0.884 & 0.609 \\
3. & Industry Factors & 0.916 & 0.737 \\
4. & Eco-Techno Environment & 0.895 & the 0.742 \\
5. & Socio-Political Environment & 0.767 & 0.530 \\
6. & The Effectiveness of Strategic & 0.850 & 0.534 \\
\hline
\end{tabular}

\subsection{Discriminant Validity}

Discriminant validity is the extent to which the measures of a construct can distinguish from another construct (Churchill, 1979). Discriminant validity is established by conducting pair-wise tests of all the related constructs as suggested by Bagozzi and Phillips (1982). This analysis verifies whether a model representing two factors fits the data better than a one-factor model (Shook et al., 2004). For each of the three pairs of factors involved, CFA was first performed by constraining correlation coefficient between the two dimensions to unity (Model 1), and then after lifting this constraint (Model 2). Positive and significant chi-square difference between the two models indicates the existence of discriminant validity between the factors involved. The results of the pair (Model 1-Model 2) wise tests are shown in Table 3 below:

Insert Table 3 here.

Thus, the chi-square differential test establishes that the measurement model which combines any of the two constructs as a single construct is not tenable. Thus, each construct proposed in this study is a distinct construct thereby establishing the discriminant validity of the proposed scale. 
CFA confirmed the validity for all the developed scales. Though the number of items has been reduced from the original list of 64 to 24 , scrutiny and discussion with experts confirmed that the removed items have similar meanings in the minds of respondents.

Table 3

Discriminant Validity - Results of Pairwise Tests

\begin{tabular}{|c|c|c|c|c|}
\hline No. & Construct 1 & Construct 2 & $\begin{array}{c}\chi^{2} / \mathrm{df} \text { of Separate } \\
\text { Construct } \\
(\mathrm{p}<0.01)\end{array}$ & $\begin{array}{c}\chi^{2} / \mathrm{df} \text { of Combin- } \\
\text { ed Construct } \\
(\mathrm{p}<0.01)\end{array}$ \\
\hline 1. & $\begin{array}{l}\text { Eco-Techno } \\
\text { Environment }\end{array}$ & $\begin{array}{l}\text { Socio-Political } \\
\text { Environment }\end{array}$ & 3.910 & 4.639 \\
\hline 2. & $\begin{array}{l}\text { Eco-Techno } \\
\text { Environment }\end{array}$ & $\begin{array}{l}\text { Organization } \\
\text { Culture }\end{array}$ & 2.716 & 17.205 \\
\hline 3. & $\begin{array}{l}\text { Eco-Techno } \\
\text { Environment }\end{array}$ & $\begin{array}{l}\text { Internal Reso- } \\
\text { urces and Tools }\end{array}$ & 3.956 & 9.455 \\
\hline 4. & $\begin{array}{l}\text { Eco-Techno } \\
\text { Environment }\end{array}$ & Industry Factor & 3.102 & 21.424 \\
\hline 5. & $\begin{array}{l}\text { Eco-Techno } \\
\text { Environment }\end{array}$ & $\begin{array}{l}\text { The Effective- } \\
\text { ness of Strate- } \\
\text { gic Investment } \\
\text { Decisions }\end{array}$ & 2.529 & 10.701 \\
\hline 6. & $\begin{array}{l}\text { Organization } \\
\text { Culture }\end{array}$ & $\begin{array}{l}\text { Internal Reso- } \\
\text { urces and Tools }\end{array}$ & 2.325 & 6.409 \\
\hline 7. & $\begin{array}{l}\text { Organization } \\
\text { Culture }\end{array}$ & $\begin{array}{l}\text { Industry } \\
\text { Factors }\end{array}$ & 2.883 & 27.770 \\
\hline 8. & $\begin{array}{l}\text { Organization } \\
\text { Culture }\end{array}$ & $\begin{array}{l}\text { The Effective- } \\
\text { ness of Strate- } \\
\text { gic Investment } \\
\text { Decisions }\end{array}$ & 1.788 & 8.088 \\
\hline 9. & $\begin{array}{l}\text { Industry } \\
\text { Factors }\end{array}$ & $\begin{array}{l}\text { The Effective- } \\
\text { ness of Strate- } \\
\text { gic Investment } \\
\text { Decisions }\end{array}$ & 2.415 & 13.793 \\
\hline 10. & $\begin{array}{l}\text { Internal } \\
\text { Resources } \\
\text { and Tools }\end{array}$ & $\begin{array}{l}\text { The Effective- } \\
\text { ness of Strate- } \\
\text { gic Investment } \\
\text { Decisions }\end{array}$ & 3.734 & 9.041 \\
\hline
\end{tabular}

\subsection{Second Order CFA}

The second order latent variables considered were internal and external factors influencing the effectiveness of strategic investment decisions. The first order latent variables under the internal factors were organization culture and internal resources and tools. The first order latent variables under the external factors were power industry factors, eco-techno environment factors and socio-political environment factors. The results of second order CFA are shown in Table 4. 
Table 4

Results of Fitness Measures Based on Second-Order CFA

\begin{tabular}{|c|c|c|c|c|c|c|}
\hline & Fitness Indices & $\chi^{2} / \mathrm{df}$ & CFI & TLI & GFI & RMSEA \\
\hline No. & $\begin{array}{l}\text { Recommended Values } \\
\text { (Marsh \& Hocevar,1985; } \\
\text { Pratarelli \& Browne, 2002) }\end{array}$ & $<=5.00$ & $>=.90$ & $>=.90$ & $>=.80$ & $<=.10$ \\
\hline 1. & $\begin{array}{l}\text { Internal Factors } \\
\text { (Organization Culture and } \\
\text { Internal Resources and } \\
\text { Tools) }\end{array}$ & 3.057 & .988 & .971 & .977 & .076 \\
\hline 2. & $\begin{array}{l}\text { External Factors } \\
\text { (Industry, Eco-Techno } \\
\text { Environment and Socio- } \\
\text { Political Environment) }\end{array}$ & 3.382 & .977 & .964 & .952 & .082 \\
\hline 3. & Overall Model & 2.489 & .982 & .974 & .952 & .065 \\
\hline
\end{tabular}

It is observed that the fitness measures for the second order CFA are within the recommended values and the scale's validity is re-established.

\subsection{Descriptive Statistics}

Table 5

The descriptive statistics for the final model is as shown in Table 5 below:

Detailed Survey Data-List of Items with Mean, Standard Deviation, Skewness and Kurtosis

\begin{tabular}{|c|c|c|c|c|c|c|c|c|c|}
\hline & \multirow{2}{*}{$\begin{array}{c}\mathbf{N} \\
\text { Statis } \\
\text {-tic }\end{array}$} & \multirow{2}{*}{$\begin{array}{l}\text { Min. } \\
\text { Statis } \\
\text {-tic }\end{array}$} & \multirow{2}{*}{$\begin{array}{c}\text { Max. } \\
\begin{array}{c}\text { Statis- } \\
\text { tic }\end{array}\end{array}$} & \multirow{2}{*}{$\begin{array}{c}\text { Mean } \\
\begin{array}{c}\text { Statis- } \\
\text { tic }\end{array}\end{array}$} & \multirow{2}{*}{$\begin{array}{c}\text { Std. } \\
\text { Dev. } \\
\text { Statis } \\
\text {-tic }\end{array}$} & \multicolumn{2}{|c|}{ Skewness } & \multicolumn{2}{|c|}{ Kurtosis } \\
\hline & & & & & & $\begin{array}{c}\text { Statis } \\
\text {-tic }\end{array}$ & $\begin{array}{l}\text { Std. } \\
\text { Error }\end{array}$ & $\begin{array}{c}\text { Statis } \\
\text {-tic }\end{array}$ & $\begin{array}{l}\text { Std. } \\
\text { Error }\end{array}$ \\
\hline T4 & 357 & 1 & 7 & 4.98 & 2.145 & -.473 & .129 & -1.566 & .257 \\
\hline PL1 & 357 & 1 & 7 & 4.89 & 1.838 & -.441 & .129 & -1.208 & .257 \\
\hline SC1 & 357 & 1 & 7 & 4.92 & 1.724 & -.533 & .129 & -.821 & .257 \\
\hline SC3 & 357 & 1 & 7 & 4.31 & 1.886 & -.028 & .129 & -1.272 & .257 \\
\hline EC2 & 357 & 1 & 7 & 5.17 & 2.047 & -.744 & .129 & -1.047 & .257 \\
\hline EC3 & 357 & 3 & 7 & 6.15 & .941 & -.890 & .129 & .362 & .257 \\
\hline MS1 & 357 & 2 & 7 & 5.47 & 1.873 & -.952 & .129 & -.682 & .257 \\
\hline GP3 & 357 & 1 & 7 & 4.64 & 1.934 & -.383 & .129 & -1.278 & .257 \\
\hline TE2 & 357 & 2 & 7 & 5.92 & 1.178 & -1.383 & .129 & 1.694 & .257 \\
\hline TE3 & 357 & 2 & 7 & 5.49 & 1.832 & -.993 & .129 & -.565 & .257 \\
\hline S2 & 357 & 1 & 7 & 4.79 & 1.878 & -.446 & .129 & -1.320 & .257 \\
\hline CW3 & 357 & 3 & 7 & 5.61 & .995 & -.591 & .129 & .301 & .257 \\
\hline IR1 & 357 & 1 & 7 & 4.80 & 1.705 & -.552 & .129 & -.958 & 257 \\
\hline IR4 & 357 & 2 & 7 & 5.57 & 1.614 & -1.006 & .129 & -.230 & .257 \\
\hline DT4 & 357 & 1 & 7 & 4.61 & 1.542 & -.388 & .129 & -.782 & .257 \\
\hline MO2 & 357 & 1 & 7 & 4.40 & 1.868 & -.183 & .129 & -1.540 & .257 \\
\hline MO4 & 357 & 1 & 7 & 4.99 & 1.499 & -.494 & .129 & -.823 & 257 \\
\hline ESDM2 & 357 & 1 & 7 & 5.18 & 1.773 & -.837 & .129 & -.660 & 257 \\
\hline ESDM3 & 357 & 2 & 7 & 5.52 & 1.621 & -1.042 & .129 & -.226 & .257 \\
\hline ESDM4 & 357 & 2 & 7 & 5.55 & 1.366 & -1.127 & .129 & .603 & .257 \\
\hline SIDec1 & 357 & 2 & 7 & 5.15 & 1.898 & -.632 & .129 & -1.219 & 257 \\
\hline SIDec3 & 357 & 1 & 7 & 5.05 & 1.878 & -.648 & .129 & -1.051 & .257 \\
\hline SIDec6 & 357 & 3 & 7 & 5.94 & 1.110 & -.867 & .129 & .113 & .257 \\
\hline
\end{tabular}




\section{HYPOTHESIS TESTING AND RESULTS}

For testing the model fit using structured equation modeling (SEM), Marsh and Hocevar (1985) suggested that the $\chi^{2} / \mathrm{df}$ ratio must preferably be less than two but ratios less than five were acceptable for a reasonable fit. $\mathrm{P}$ value must be statistically insignificant to indicate a good fit. Goodness of Fit (GFI), Comparative Fit Index (CFI) and Tucker and Lewis Fit Index (TLI) values must preferably be greater than 0.9 but values greater than 0.8 were acceptable for reasonable fit (Byrne, 2001). For a better fit, the Root Mean Square Error of Approximation (RMSEA) should be less than 0.05. However, for reasonable fit, the RMSEA can be less than 0.1 (Pratarelli \& Browne, 2002).

Initially, all independent variables were considered to influence the effectiveness of strategic investment decisions. In the next round of iteration, a relationship was considered among the independent variables. 11 alternate models were tested to identify the intra and inter-relationships of organization culture, internal resources and tools, industry, eco-techno environment and socio-political environment factors, over the effectiveness of strategic investment decisions. Based on the comparison of $\chi^{2} / \mathrm{df}$, CFI and GFI values for all the proposed models, the model is shown in Figure 3, demonstrating the relationship of internal, industry and economy factors, with the effectiveness of the strategic investment decision making is accepted for further analysis.

$\chi^{2} / \mathrm{df}$ for the impact of the overall model was 3.904, which is less than 5; CFI was 0.911 , TLI was 0.901 all of which are above 0.90 and GFI was 0.838 which is above 0.80; RMSEA was 0.09 which is below 0.10 . These fit measures were adequate and within limits. All the regression weights were above 0.4 , indicating good construct validity.

\section{Figure 3}

\section{Final SEM Model}

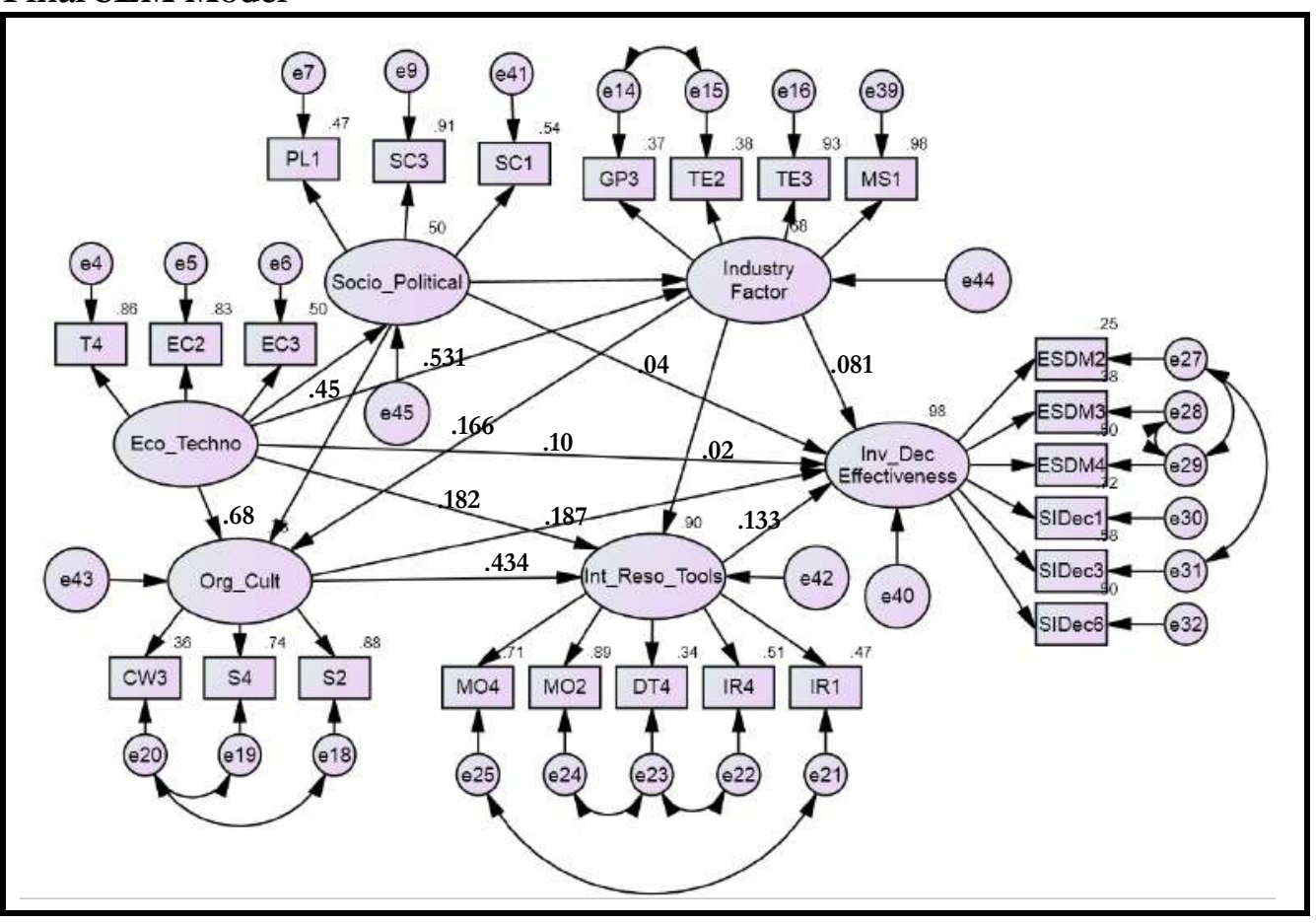




\subsection{Hypothesis Testing}

All the hypotheses were tested using AMOS V.20. The t-value results obtained are as shown in Table 6. The t-value results for all hypotheses indicated that, based on statistically significant results, the hypotheses need to be accepted except $\mathrm{H}_{2}, \mathrm{H}_{5}, \mathrm{H}_{7}$, $\mathrm{H}_{8}, \mathrm{H}_{10}$ and $\mathrm{H}_{14}$ at a significance level of 0.05 .

Table 6

Hypothesis Testing Results for Proposed Model

\begin{tabular}{|c|c|c|c|c|c|c|}
\hline $\begin{array}{l}\text { Hypo- } \\
\text { theses }\end{array}$ & $\begin{array}{l}\text { Interaction } \\
\text { Relationship }\end{array}$ & $\begin{array}{c}\text { Std. } \\
\text { Regre. } \\
\text { Weight }\end{array}$ & S.E. & $\begin{array}{c}\text { C.R. } \\
(\mathrm{t}- \\
\text { values })\end{array}$ & $\mathbf{P}$ & Remarks \\
\hline $\mathbf{H}_{1}$ & $\begin{array}{l}\text { Org. Cult } \rightarrow \\
\text { Inv_Dec_Effectiveness }\end{array}$ & 0.187 & 0.048 & 3.895 & $* * *$ & Supported \\
\hline $\mathbf{H}_{2}$ & $\begin{array}{l}\text { Int_Reso_Tools } \rightarrow \\
\text { Inv_Dec_Effectiveness }\end{array}$ & 0.133 & 0.078 & 1.704 & 0.088 & Rejected \\
\hline $\mathbf{H}_{3}$ & $\begin{array}{l}\text { Industry_Factor } \rightarrow \\
\text { Inv_Dec_Effectiveness }\end{array}$ & 0.081 & 0.033 & 2.482 & 0.013 & Supported \\
\hline $\mathbf{H}_{4}$ & $\begin{array}{l}\text { Eco_Techno } \rightarrow \\
\text { Inv_Dec_Effectiveness }\end{array}$ & 0.104 & 0.036 & 2.88 & 0.004 & Supported \\
\hline $\mathbf{H}_{5}$ & $\begin{array}{l}\text { Socio_Political } \rightarrow \\
\text { Inv_Dec_Effectiveness }\end{array}$ & 0.042 & 0.025 & 1.694 & 0.09 & Rejected \\
\hline $\mathbf{H}_{6}$ & $\begin{array}{l}\text { Org_Cult } \rightarrow \\
\text { Int_Reso_Tools }\end{array}$ & 0.434 & 0.05 & 8.753 & $* * *$ & Supported \\
\hline $\mathbf{H}_{7}$ & $\begin{array}{l}\text { Industry_Factor } \rightarrow \\
\text { Org_Cult }\end{array}$ & 0.166 & 0.105 & 1.586 & 0.113 & Rejected \\
\hline $\mathbf{H}_{8}$ & $\begin{array}{l}\text { Industry_Factor } \rightarrow \\
\text { Int_Reso_Tools }\end{array}$ & 0.023 & 0.047 & 0.493 & 0.622 & Rejected \\
\hline $\mathrm{H}_{9}$ & $\begin{array}{l}\text { Eco_Techno } \rightarrow \\
\text { Industry_Factor }\end{array}$ & 0.531 & 0.05 & 10.611 & $* * *$ & Supported \\
\hline $\mathbf{H}_{10}$ & $\begin{array}{l}\text { Socio_Political } \rightarrow \\
\text { Industry_Factor }\end{array}$ & -0.097 & 0.051 & -1.907 & 0.056 & Rejected \\
\hline $\mathbf{H}_{11}$ & $\begin{array}{l}\text { Eco_Techno } \rightarrow \\
\text { Socio_Political }\end{array}$ & 0.452 & 0.04 & 11.286 & $* * *$ & Supported \\
\hline $\mathbf{H}_{12}$ & $\begin{array}{l}\text { Eco_Techno } \rightarrow \\
\text { Org_Cult }\end{array}$ & 0.684 & 0.082 & 8.348 & $* * *$ & Supported \\
\hline $\mathbf{H}_{13}$ & $\begin{array}{l}\text { Eco_Techno } \rightarrow \\
\text { Int_Reso_Tools }\end{array}$ & 0.182 & 0.044 & 4.135 & $* * *$ & Supported \\
\hline $\mathbf{H}_{14}$ & $\begin{array}{l}\text { Socio_Political } \rightarrow \\
\text { Org_Cult }\end{array}$ & -0.025 & 0.077 & -0.317 & 0.751 & Rejected \\
\hline
\end{tabular}

It was noticed that organization culture factor played a very significant role in the effectiveness of strategic decision making in the power sector. Organization culture factor was more important compared to internal resources and tools. The industry factor and eco-techno environment factor positively influenced the effectiveness of investment decisions. However, eco-techno environmental factor was found to be more important compared to that of industry factors for the effectiveness of strategic investment decisions in the power sector. It was noted that the internal resources and tools, and socio-political environment did not have a positive impact on the effectiveness of investment decisions at 95\% confidence level. This result is not in alignment with the resource-based view of strategic decisions (Wernerfelt, 1984; 
Barney, 2001a; and Barney, 2001b). The respondents have favored the presence of organizational culture, conducive industry and eco-techno environment factors for ensuring the success of investment decisions.

It was also observed that economic and technological factors positively impacted all other factors that are, organization culture, internal resources and tools, industry factors and socio-politico environment. It was also found that organization culture significantly influenced the internal resources and tools of a firm.

Organizational culture has been noted to play a significant role in driving organizational performance. It is said that culture eats strategy for breakfast. This result is in alignment with the findings of other researchers. This result supports the findings of Prajogo and McDermott (2011) who also report a positive relationship between culture and performance. Organizational culture has been found to influence organization operations, people decisions, and decisions and performance (Wu et al., 2011). Culture is a key to organizational excellence (Schein, 1984). Samson and Terziovski (1999) have shown that "soft" elements such as leadership, human resources management and customer focus are stronger predictors of organization performance than systems and analytically oriented criteria. Lee and $\mathrm{Yu}$ (2004) found that "organizational culture" is the non-tangible aspect of organizational studies for driving business performance. Misalignment of organizational culture with the environment has been one of the major reasons for poor business performance. If the culture is aligned with employees' values, the chances of the organization's success are maximized. Organization culture that supports collaboration, cooperation and teamwork has been a major factor in achieving business goals. It is argued that a team of strong leaders can make a huge difference, rather than just one right leader at the top (Lee \& Yu, 2004).

\subsection{Interaction Effects}

Interaction effects are generally used to identify the non-additive effects that are, when the joint effects $\mathrm{X}$ and $\mathrm{Z}$ on $\mathrm{Y}$ are more or less than their additive effects (Hair et al., 2010).

Table 7 provides the interaction effects tested along with the final results of this research study. The values of latent variables were calculated using the method of data imputation.

Insert Table 7 here.

It is also observed that the internal resources and tools, and socio-political, environmental factors have remained insignificant after interaction effects were incorporated into the model. There are only two out of ten interaction effects that are significant and positively influence the effectiveness of strategic investment decisions. These interaction effects are of IRT (Internal resources and tools) with SP (sociopolitical environment) and SP (socio-political environment) with ET (eco-techno environment). Each of these interaction effects is plotted below (please refer to Figure 4 and Figure 5) and explanation is given for the effect of the moderating variable.

Both socio-political environment, and internal resources and tools factors, have not been found to influence the success of investment decisions. However, as shown in Figure 4, it is observed that the socio-political environment strengthens a positive relationship between internal resources and tools, and the effectiveness of strategic investment decisions. 
Figure 4

Interaction Effect of Internal Resources and Tools and Socio-Politico Environment on Strategic Investment Decisions

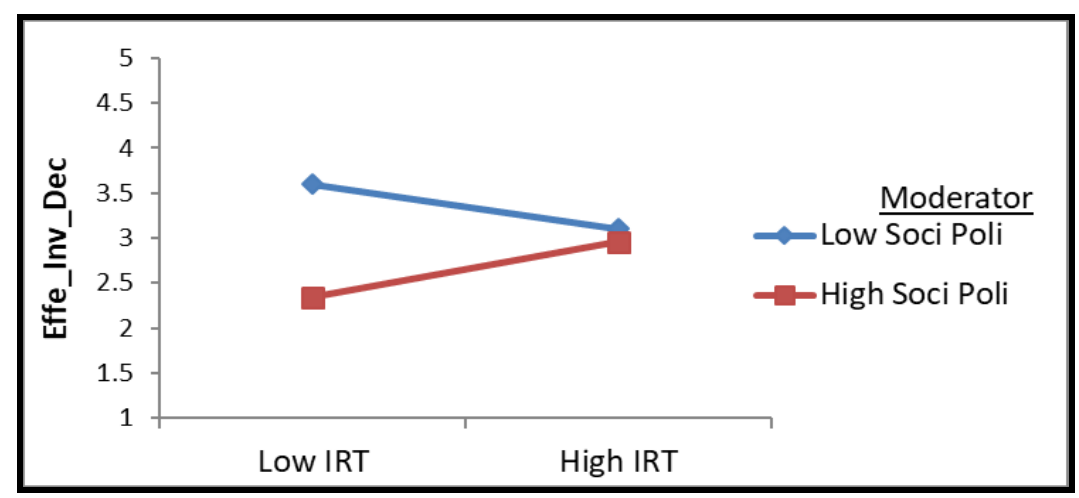

The graph in Figure 4 is highly valid in the Indian socio-political environment since India supports companies that have low internal resources and tools (Indian government provides a subsidy to economically weaker institutions). It may or may not be true in other countries as the socio-political environment is different in different countries.

\section{Figure 5}

Interaction Effect of Eco-Techno and Socio-Politico Environment on Strategic Investment Decisions

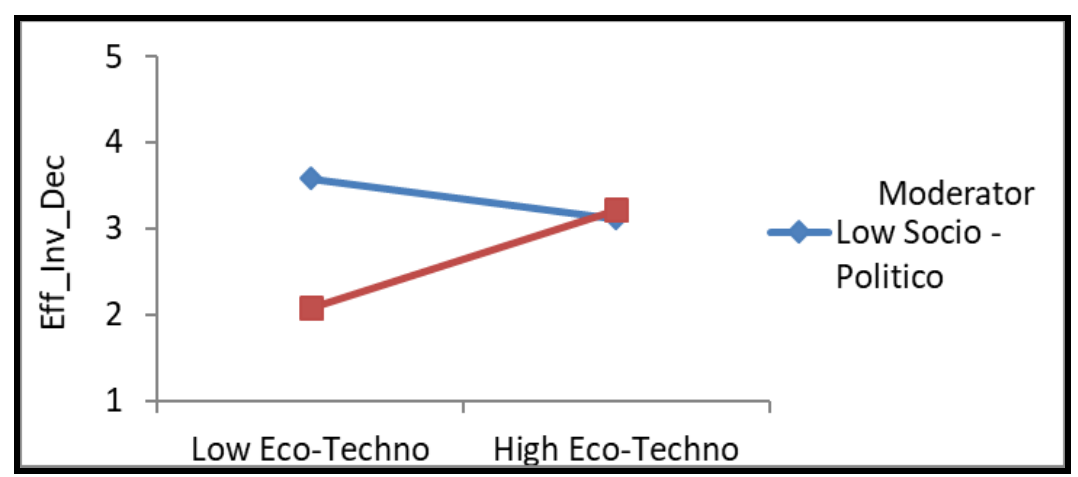

As shown in Figure 5, socio-political environment strengthens the positive relationship between eco-techno environment and the effectiveness of strategic investment decisions. Social and political conditions determine the economic stability, collaborative and cooperative culture, long-term policies etc., which in turn influences the economic and technological environment's effect on the effectiveness of investment decisions. For example, it was observed that setting up a retail chain in certain parts of India was beneficial to all the relevant stakeholders (key suppliers and end consumers), however it affected the social and political structure due to its effect on the livelihood of small retail shop owners and in turn, their support to the ruling political party. Technology deployed in business can drive leadership behavior, impacting investment decisions and their results in the long run. Social and political environment largely influences the personal and social values of an individual. These values, in turn, determine whether these individuals will collaborate and consider each other as competitors while working on the implementation of investment decisions. 
Excellence in execution is considered to be a key to getting positive results out of strategic investment decisions (Liu, 2013).

Table 7

Analysis of Interaction Effects among Independent Latent Variables

\begin{tabular}{|c|c|c|c|c|c|c|}
\hline $\begin{array}{l}\text { Hypo- } \\
\text { theses }\end{array}$ & $\begin{array}{l}\text { Interaction } \\
\text { Relationship }\end{array}$ & $\begin{array}{c}\text { Std. regre. } \\
\text { Weight }\end{array}$ & S.E. & $\begin{array}{l}\text { C.R. (t- } \\
\text { values) }\end{array}$ & $\mathbf{P}$ & Remarks \\
\hline $\mathbf{H}_{6 a}$ & $\begin{array}{l}\text { Inv_Dec } \leftarrow \\
\text { OC_X_IRT }\end{array}$ & -0.008 & 0.022 & -0.361 & 0.718 & Rejected \\
\hline $\mathbf{H}_{7 \mathrm{a}}$ & $\begin{array}{l}\text { Inv_Dec } \leftarrow \\
\text { OC_X_IF }\end{array}$ & -0.058 & 0.018 & 3.298 & $* * *$ & Rejected \\
\hline $\mathbf{H}_{8 \mathrm{a}}$ & $\begin{array}{l}\text { Inv_Dec } \leftarrow \\
\text { IRT_X_IF }\end{array}$ & 0.189 & 0.146 & 1.297 & 0.195 & Rejected \\
\hline $\mathbf{H}_{9 \mathrm{a}}$ & $\begin{array}{l}\text { Inv_Dec } \leftarrow \\
\text { IF_X_ET }\end{array}$ & -0.073 & 0.010 & -7.176 & $* * *$ & Rejected \\
\hline $\mathbf{H}_{10 \mathrm{a}}$ & $\begin{array}{l}\text { Inv_Dec } \leftarrow \\
\text { IRT_X_SP }\end{array}$ & 0.023 & 0.010 & 2.333 & 0.020 & Supported \\
\hline $\mathbf{H}_{11 \mathrm{a}}$ & $\begin{array}{l}\text { Inv_Dec } \leftarrow \\
\text { SP_X_ET }\end{array}$ & 0.029 & 0.012 & 2.505 & 0.012 & Supported \\
\hline $\mathbf{H}_{12 \mathrm{a}}$ & $\begin{array}{l}\text { Inv_Dec } \leftarrow \\
\text { OC_X_ET }\end{array}$ & -0.003 & 0.006 & -0.516 & 0.606 & Rejected \\
\hline $\mathbf{H}_{13 \mathrm{a}}$ & $\begin{array}{l}\text { Inv_Dec } \leftarrow \\
\text { IRT_X_ET }\end{array}$ & 0.031 & 0.023 & 1.361 & 0.173 & Rejected \\
\hline $\mathbf{H}_{13 \mathrm{~b}}$ & $\begin{array}{l}\text { Inv_Dec } \leftarrow \\
\text { IF_X_SP }\end{array}$ & -0.004 & 0.016 & -.283 & 0.777 & Rejected \\
\hline $\mathbf{H}_{14 a}$ & $\begin{array}{l}\text { Inv_Dec } \leftarrow \\
\text { OC_X_SP }\end{array}$ & -0.054 & 0.004 & -12.331 & $* * *$ & Rejected \\
\hline $\mathbf{H}_{1}$ & $\begin{array}{l}\text { Inv_Dec } \leftarrow \\
\text { Org_Cul }\end{array}$ & 0.215 & 0.042 & 5.175 & $* * *$ & Supported \\
\hline $\mathbf{H}_{2}$ & $\begin{array}{l}\text { Inv_Dec } \leftarrow \\
\text { Int_Res_Tools }\end{array}$ & 0.028 & 0.071 & 0.393 & 0.694 & Rejected \\
\hline $\mathbf{H}_{3}$ & $\begin{array}{l}\text { Inv_Dec } \leftarrow \\
\text { Indu }\end{array}$ & 0.230 & 0.035 & 6.624 & $* * *$ & Supported \\
\hline $\mathbf{H}_{4}$ & $\begin{array}{l}\text { Inv_Dec } \leftarrow \\
\text { Eco_Tech }\end{array}$ & 0.133 & 0.061 & 2.181 & 0.029 & Supported \\
\hline $\mathbf{H}_{5}$ & $\begin{array}{l}\text { Inv_Dec } \leftarrow \\
\text { Soc_Poli }\end{array}$ & -0.269 & 0.123 & -2.192 & 0.028 & Rejected \\
\hline
\end{tabular}

\subsection{Multi-Group Moderation Tests}

It was decided to test whether the characteristics of the decision makers such as age, experience, job level etc., have any effect on the effectiveness of strategic investment decision making. In this research, the focus was only on job level differences. The hypothesis considered was whether there is any significant difference among leaders having different job levels, on the effectiveness of strategic investment decisions. The results of tests for two groups, top management (TM) and middle management $(\mathrm{MM})$, are presented in Table 8. 
Table 8

Multigroup Analysis Based on Job Level of the Decision Makers

\begin{tabular}{|c|c|c|c|c|c|c|}
\hline \multirow{2}{*}{ No. } & \multirow{2}{*}{$\begin{array}{c}\text { Interaction } \\
\text { Relationship }\end{array}$} & \multicolumn{2}{|c|}{$\mathrm{MM}(\mathrm{N}=100)$} & \multicolumn{2}{|c|}{ TM (N=257) } & \multirow{2}{*}{ Z-Score } \\
\hline & & Estimate & $\mathbf{P}$ & Estimate & $\mathbf{P}$ & \\
\hline 1. & $\begin{array}{l}\text { Soc_Poli } \leftarrow \\
\text { Eco_Tech }\end{array}$ & 0.646 & 0.000 & 0.649 & 0.000 & 0.027 \\
\hline 2. & $\begin{array}{l}\text { Indu } \leftarrow \\
\text { Eco_Tech }\end{array}$ & 0.610 & 0.000 & 0.759 & 0.000 & $1.727^{*}$ \\
\hline 3. & $\begin{array}{l}\text { Indu } \leftarrow \\
\text { Soc_Poli }\end{array}$ & 0.067 & 0.331 & 0.004 & 0.939 & -0.744 \\
\hline 4. & $\begin{array}{l}\text { Org_Cul } \leftarrow \\
\text { Indu }\end{array}$ & 0.330 & 0.000 & 0.365 & 0.000 & 0.332 \\
\hline 5. & $\begin{array}{l}\text { Org_Cul } \leftarrow \\
\text { Soc_Poli }\end{array}$ & -0.030 & 0.632 & 0.013 & 0.748 & 0.577 \\
\hline 6. & $\begin{array}{l}\text { Org_Cul } \leftarrow \\
\text { Eco_Tech }\end{array}$ & 0.387 & 0.000 & 0.402 & 0.000 & 0.149 \\
\hline 7. & $\begin{array}{l}\text { Int_Res_Tools } \\
\leftarrow \text { Org_Cul }\end{array}$ & 0.494 & 0.000 & 0.505 & 0.000 & 0.130 \\
\hline 8. & $\begin{array}{l}\text { Int_Res_Tools } \\
\leftarrow \text { Indu }\end{array}$ & 0.237 & 0.000 & 0.215 & 0.000 & -0.281 \\
\hline 9. & $\begin{array}{l}\text { Int_Res_Tools } \\
\leftarrow \text { Eco_Tech }\end{array}$ & 0.150 & 0.007 & 0.175 & 0.000 & 0.348 \\
\hline 10. & $\begin{array}{l}\text { Inv_Dec } \leftarrow \\
\text { Eco_Tech }\end{array}$ & 0.249 & 0.000 & 0.232 & 0.000 & -0.210 \\
\hline 11. & $\begin{array}{l}\text { Inv_Dec } \leftarrow \\
\text { Soc_Poli }\end{array}$ & 0.108 & 0.014 & 0.003 & 0.923 & $-1.956^{*}$ \\
\hline 12. & $\begin{array}{l}\text { Inv_Dec } \leftarrow \\
\text { Indu }\end{array}$ & 0.202 & 0.005 & 0.224 & 0.000 & 0.262 \\
\hline 13. & $\begin{array}{l}\text { Inv_Dec } \leftarrow \\
\text { Org_Cul }\end{array}$ & 0.261 & 0.003 & 0.206 & 0.000 & -0.526 \\
\hline 14. & $\begin{array}{l}\text { Inv_Dec } \leftarrow \\
\text { Int_Res_Tools }\end{array}$ & 0.050 & 0.644 & 0.164 & 0.003 & $0.933^{*}$ \\
\hline
\end{tabular}

Notes: ${ }^{* * *}$ p-value $<0.01 ;{ }^{* *}$ p-value $<0.05 ;$ and ${ }^{*}$ p-value $<0.10$.

It is noted that, based on the perception of the top management, all independent variables, except socio-political environment factors, had a positive impact on the effectiveness of strategic decisions. Further, based on the perception of the middle management, all independent variables, except internal resources and tools, had a positive impact on the effectiveness of strategic decisions. Based on the z-values, it is concluded that the following paths differ in the confidence of $90 \%$ based on the management level in a power sector organization:

1) Effect of socio-politico environment factors on investment decisions.

2) Effect of internal resources and tools on investment decisions.

3) Effect of eco-techno environment factors on industry factor. 


\section{CONCLUSION, DISCUSSION, LIMITATIONS AND OPPORTUNITIES}

\subsection{Conclusion and Discussion}

The study conceptualized a framework to capture the perceptions of decision makers in the power sector about various dimensions of strategic investment decisions. This study identified five latent variables which significantly influenced the effectiveness of strategic investment decisions. It was observed that three latent variables independently impacted the success of investment decisions. However, two of the latent variables did not positively determine the success of investment decisions. Moreover, their interaction effect had a positive effect on the success of investment decisions. Hence, it can be concluded that these five latent variables, either independently or through interaction effects, played a significant role in determining the success of investment decisions.

The discussion on the testing of hypotheses and statistical evidence was carried out which led to the acceptance of most of the hypotheses. The evidence also supported that there is a positive interaction effect of IRT (Internal resources and tools) with SP (socio-political environment) and SP (socio-political environment) with ET (eco-techno environment).

Our study addresses a gap in the literature and advances the knowledge of the effectiveness of strategic decision making. This study empirically validated that organization culture factor influences the effectiveness of strategic decision making more, as compared to internal resources. It is essential that managers inculcate the habit of thinking not only about the person's capabilities but also about the organization's capabilities. The degree of collaboration among decision makers has emerged as the key factor in deciding the effectiveness of strategic decisions. This is supported by Collins and Porras (1996) and Hemp and Stewart (2004). Building a visionary company requires $1 \%$ vision and 99\% alignment (Rogers \& Blenko, 2006). Most of the critical decisions for a firm cut across functions. Therefore, cross-functional collaboration has become a necessity of business. It helps in creating win-win solutions for all the stakeholders and in optimizing the utilization of available hard and soft resources. Based on the expert discussion, it was noted that fluid decision making across functional teams remains a constant challenge, even for companies known for doing it well such as Toyota and GM.

Industry factors such as a shift in preference to newer technologies like nuclear power or renewable power over coal-based technologies demand to trade in power related futures, rising need of large-scale financial investment and the ability to identify high-risk areas, are observed to have a significant impact on the effectiveness of strategic investment decisions. Economy factors such as encouraging technological innovations, removing regulatory barriers, encouraging foreign investment, monitoring foreign currency fluctuations, the impact of socio-cultural forces in fostering egalitarianism, are observed to have a significant impact on the effectiveness of strategic investment decisions.

The findings of this study have shown a similarity with the findings of strategic decisions taken in some Chinese and British firms (Lu \& Heard, 1995). The findings also support similar observations by Lai et al. (2015) when they studied the drivers behind rapid economic development in the last decade in Japan, Korea, China, Taiwan, Hong Kong and Singapore. As per their findings, the controllability of internal factors was far more important than external factors. 
The findings of this study concerning internal resources do not support the resource-based view of strategic decisions (Wernerfelt, 1984; Barney, 2001a, and Barney, 2001b). Strategic investment decisions are mostly concerned with bringing a change in the status quo of a firm. These changes can only be brought in by leaders who focus on what is right, mobilize the commitment of organization's key stakeholders and align everyone in the execution of the change plan (Kim \& Mauborgne, 2004). This is also related to the organization culture dimension of this research study. Personal learning for effective leadership development cannot occur in the classroom. It only happens in an organization where teamwork, high commitment and relevant competencies are part of the organization culture (Beer et al., 1990).

This research extends the reasoning of Porter's (2008) five competitive forces of industry structure by incorporating the industry and economic forces as essential components for defining business strategy. A key implication of this study for practising managers is that firms need to take into consideration both firm-specific factors (resources and organization culture) as well as market-based factors (the external environment) while making strategic investment decisions, as each of these factors can potentially affect the development of competitive advantage. Stuckey (1990) suggested that to qualify as special; a capability had to result in either significantly lower costs or better products.

\subsection{Limitations and Opportunities for Further Research}

The findings of this study are based on the perceptions of senior executives working in the power sector in India. The hypothesis considered in this study could be tested in other settings, perhaps a different economy or different industry sector. Other demographic variables can also be considered such as age, leadership style, organization's past performance, existence period of an organization, etc., as control variables. Furthermore, this was a cross-sectional study that did not address the performance of investment decisions in the power sector over time. In the future, longitudinal studies might be conducted to investigate whether and how transitions occur in value creation. This study could also be extended to other sectors of the economy to ascertain whether the same results are obtained. The comparative study of the effectiveness of strategic decisions in various sectors/nations could be another opportunity for extending this research. Hence, as part of the future research, studies could obtain longitudinal data or use different sources of data for predictor and criterion variables. One can also deep dive into each of the internal, industry and economy factors, to understand the relationship between various sub-dimensions impacting the effectiveness of strategic decisions.

\section{REFERENCES}

Adcroft, A., Willis, R., \& Hurst, J. (2008). A new model for managing change: The holistic view. Journal of Business Strategy, 29(1), 40-45.

Amram, M., \& Kulatilaka, N. (1999). Uncertainty: The new rules for strategy. The Journal of Business Strategy, 20(3), 25-29.

Andersen, J. A., \& Jonsson, P. (2006). Does organization structure matter? On the relationship between the structure, functioning and effectiveness. International Journal of Innovation \& Technology Management, 3(3), 237-263.

Andrews, R. (2010). Organizational social capital, structure and performance. Human Relations, 63(5), 583-608. 
Asrilhant, B., Meadows, M., \& Dyson, R. G. (2004). Exploring decision support and strategic project management in the oil and gas sector. European Management Journal, 22(1), 63-73.

Attig, N., Cleary, S. W., El Ghoul, S., \& Guedhami, O. (2014). Corporate legitimacy and investment-cash flow sensitivity. Journal of Business Ethics, 121(2), 297-314.

Bae, J., \& Lawler, J. J. (2000). Organizational and HRM strategies in Korea: Impact on firm performance in an emerging economy. Academy of Management Journal, 43(3), 502-517.

Bagozzi, R. P., \& Phillips, L. W. (1982). Representing and testing organizational theories: A holistic construal. Administrative Science Quarterly, 27(3), 459-489.

Bagozzi, R. P., \& Yi, Y. (1988). On the evaluation of structural equation models. Academy of Management Science, 16(1), 74-94.

Baligh, H. H., Burton, R. M., \& Obel, B. (1996). Organizational consultant: Creating a useable theory for organizational design. Management Science, 42(12), 1648-1662.

Barney, J. B. (2001a). Is the resource-based "view" a useful perspective for strategic management research? Yes. The Academy of Management Review, 26(1), 41-56.

Barney, J. B. (2001b). Resource-based theories of competitive advantage: A ten-year retrospective on the resource-based view. Journal of Management, 27(6), 643-650.

Beer, M., Eisenstat, R. A., \& Spector, B. (1990). Why change programs don't produce change. Harvard Business Review, 68(6), 158-166.

Byrne, B. M. (2001). Structural equation modeling with AMOS, EQS, and LISREL: Comparative approaches to testing for the factorial validity of a measuring instrument. International Journal of Testing, 1(1), 55-86.

Carlstein, T. (1982). Time resources, society, and ecology: On the capacity for buman interaction in space and time. London: Allen and Unwin.

Carpenter, M. A., Sanders, W. G., \& Gregersen, H. B. (2001). Bundling human capital with organizational context: The impact of international assignment experience on multinational firm performance and CEO pay. Academy of Management Journal, 44(3), 493-511.

Chen, S., Yoshino, H., \& Li, N. (2010). Statistical analyses on summer energy consumption characteristics of residential buildings in some cities of China. Energy \& Buildings, 42(1), 136-146.

Chmielewski, D. A. (2010). A conceptual exploration of the strategic factors driving new brand entry decisions and their success. Australasian Marketing Journal, 18(2), 66-73.

Chou, Y. C., Cheng, C. T., Yang, F. C., \& Liang, Y. Y. (2007). Evaluating alternative capacity strategies in semiconductor manufacturing under uncertain demand and price scenarios. International Journal of Production Economics, 105(2), 591-606.

Churchill, Jr. G. A. (1979, February). A paradigm for developing better measures of marketing constructs. Journal of Marketing Research, 16, 64-73.

Collins, J. C, \& Porras, J. I. (1996). Building a visionary company's vision. Harvard Business Review, 74(5), 65-77.

Collis, D. J. (1991). A resource-based analysis of global competition: The case of the bearings industry. Strategic Management Journal, 12(S1), 49-68.

Corley, K. G. (2004). Defined by our strategy or our culture? Hierarchical differences in perceptions of organizational identity and change. Human Relations, 57(9), 11451177.

Daft, R. L., \& Lewin, A. Y. (1993). Where are the theories for the "new" organizational forms? An editorial essay. Organization Science, 4(4), 1-6. 
Dendena, B., \& Corsi, S. (2015, December). The environmental and social impact assessment: A further step towards an integrated assessment process. Journal of Cleaner Production, 108(PA), 965-977.

Deshpande, R., \& Webster Jr., F. E. (1989). Organizational culture and marketing: Defining the research agenda. Journal of Marketing, 53(1), 3-15.

DeVellis, R. F. (2003). Scale development: Theory and applications (2 ${ }^{\text {nd }}$ Ed.). New Delhi: Sage Publication.

Domínguez-Gómez, J. A. (2016, January). Four conceptual issues to consider in integrating social and environmental factors in risk and impact assessments. Environmental Impact Assessment Review, 56, 113-119.

Drummond, H. (2014). Escalation of commitment: When to stay the course? Academy of Management Perspectives, 28(4), 430-446.

Eisenhardt, K. M., \& Schoonhoven, C. B. (1990). Organizational growth: Linking founding team, strategy, environment, and growth among U.S. semiconductor ventures, 1978-1988. Administrative Science Quarterly, 35(3), 504-529.

Elbanna, S., Thanos, L. C., \& Colak, M. (2015). An exploratory study of the determinants of the quality of strategic decision implementation in Turkish industrial firms. Journal of General Management, 40(2), 27-46.

Elenkov, D. S., \& Manev, I. M. (2005). Top management leadership and influence on innovation: the role of sociocultural context. Journal of Management, 31(3), 381402.

Fornell, C., \& Larcker, D. F. (1981). Structural equation models with unobservable variables and measurement error: Algebra and statistics. Journal of Marketing Research, 18(3), 382-388.

Glass, R. S., \& Wood, W. A. (1996). Situational determinants of software piracy: An equity theory perspective. Journal of Business Ethics, 15(11), 1189-1198.

Greer, C. R., \& Stephens, G. K. (2001). Escalation of commitment: A comparison of differences between Mexican and U.S. decision-makers. Journal of Management, 27(1), 51-78.

Hair, J. F., Tatham, R. L., Anderson, R. E., \& Black, W. (2010). Multivariate Data Analysis. Upper Saddle River, NJ: Pearson Prentice Hall.

Hall, C., \& Lundberg, D. (2010). Competitive knowledge and strategy in high-velocity environments. The IUP Journal of Knowledge Management, 8(1-2), 7-17.

Hamel, G., \& Prahalad, C. K. (1994). Competing for the future. Harvard Business Review, 72(4), 122-128.

Hampson, I. (2012). Industry policy under economic liberalism: Policy development in the prime minister's manufacturing task force. The Economic \& Labour Relations Review, 23(4), 39-56.

Hemp, P., \& Stewart, T. A. (2004). Leading change when business is good. Harvard Business Review, 82(12), 60-70.

Hofstede, G. (1980) Motivation, leadership, and organization: Do American theories apply abroad? Organizational Dynamics, 9(1), 42-63.

Hult, G. T. M., \& Ketchen Jr., D. J. (2001). Does market orientation matter? A test of the relationship between positional advantage and performance. Strategic Management Journal, 22(9), 899-906.

Huyen, L. H. B. (2015). Determinant of the factors affecting foreign direct investment (FDI) flow to Thanh Hoa Province in Vietnam. Procedia-Social \& Behavioral Sciences, 172, 26-33. 
Jackson, J. (2010). Promoting energy efficiency investments with risk management decision tools. Energy Policy, 38(8), 3865-3873.

Jager, K. (2013). Sources of Franco-German corporate support for the euro: The effects of business network centrality and political connections. European Union Politics, 14(1), 115-139.

Jaworski, B. J., \& Kohli, A. K. (1993). Market orientation: Antecedents and consequences. Journal of Marketing, 57(3), 53-70.

Kang, H. (2005). A model of strategy formulation and implementation for service technology. Strategic Change, 14(4), 231-238.

Lee, S. K. J., \& Yu, K. (2004). Corporate culture and organizational performance. Journal of Managerial Psychology, 19(4), 340-359.

Kim, W. C., \& Mauborgne, R. (2004). Blue ocean strategy. Harvard Business Review, 82(10), 76-84.

Kim, W. C., \& Mauborgne, R. (2009). How Strategy Shapes Structure. Harvard Business Review, 87(9), 72-80.

Klepper, S. (1997). Industry life cycles. Industrial \& Corporate Change, 6(1), 145-182.

Kogut, B., \& Kulatilaka, N. (1994). Options thinking and platform investments: Investing in opportunity. California Management Review, 36(2), 52-71.

Kouvelis, P., \& Tian, Z. (2014). Flexible capacity investments and product mix: Optimal decisions and value of postponement options. Production \& Operations Management, 23(5), 861-876.

Kozloff, K. L. (1994). Renewable energy technology: An urgent need, a hard sell. Environment, 36(9), 4-16.

Krychowski, C., \& Quélin, B. V. (2010). Real options and strategic investment decisions: Can they be of use to scholars? Academy of Management Perspectives, 24(2), 65-78.

Lai, Y. L., Lin, F. J., \& Lin, Y. H. (2015). Factors affecting firm's R\&D investment decisions. Journal of Business Research, 68(4), 840-844.

Lee, J., \& Miller, D. (1999). People matter: Commitment to employees, strategy and performance in Korean firms. Strategic Management Journal, 20(6), 579-593.

Lin, B., \& Yang, L. (2013). The potential estimation and factor analysis of China's energy conservation on thermal power industry. Energy Policy, 62, 354-362.

Liu, Y. (2013). Sustainable competitive advantage in turbulent business environments. International Journal of Production Research, 51(10), 2821-2841.

Lu, Y., \& Heard, R. (1995). Socialized economic action: A comparison of strategic investment decisions in China and Britain. Organization Studies, 16(3), 395-424.

Marsh, H. W., \& Hocevar, D. (1985). Application of confirmatory factor analysis to the study of self-concept: First- and higher order factor models and their invariance across groups. Psychological Bulletin, 97(3), 562-582.

Merino, F., \& Rodríguez, D. R. (1997). A consistent analysis of diversification decisions with non-observable firm effects. Strategic Management Journal, 18(9), 733-743.

Merriman, K. K., \& Sen, S, (2012). Incenting managers toward the triple bottom line: An agency and social norm perspective. Human Resource Management, 51(6), 851871.

Miller, D. (1986). Configurations of strategy and structure: Towards a synthesis. Strategic Management Journal, 7(3), 233-249.

Mohanty, A., \& Mohanty, B. (2014). Power sector efficiency-a review. Vilakshan: The XIMB Journal of Management, 11(1), 83-110. 
Almfraji, M. A., \& Almsafir, M. K. (2014). Foreign direct investment and economic growth literature review from 1994 to 2012. Procedia-Social \& Behavioral Sciences, 129, 206-213.

Narver, J. C., \& Slater, S. F. (1990). The effect of a market orientation on business profitability. Journal of Marketing, 54(4), 20-35.

Nicholls, J. R. (1984). An alloplastic approach to corporate culture. International Studies of Management \& Organization, 14(4), 32-63.

Pandza, K., Horsburgh, S., Gorton, K., \& Polajnar, A. (2003). A real options approach to managing resources and capabilities. International Journal of Operations \& Production Management, 23(9), 1010-1032.

Peng, M. W. (2001). The resource-based view and international business. Journal of Management, 27(6), 803-829.

Pheng, L. S., \& Chuan, Q. T. (2006). Environmental factors and work performance of project managers in the construction industry. International Journal of Project Management, 24(1), 24-37.

Phulpagar, S. A., \& Maddulety, K. (2011). Review of models used for selection of corporate strategies. Management Prudence, 2(1), 57-68.

Phulpagar, S. A., \& Maddulety, K. (2013). Study of strategic decisions and underlying factors influencing them for the corporate. International Journal of Management Research \& Business Strategy, 2(4), 73-97.

Porter, M. E. (1987). From Competitive Advantage to Corporate Strategy. Cambridge, MA: Harvard Business Review.

Porter, M. E. (2008). The five competitive forces that shape strategy. Harvard Business Review, 86(1), 78-93.

Posner, M. V. (1993). Electricity and the primary fuels: Technology, market structure and prices. National Institute Economic Review, 145(1), 64-86.

Prajogo, D. I., \& McDermot, C. M. (2011). The relationship between multidimensional organizational culture and performance. International Journal of Operations \& Production Management, 31(7), 712-735.

Pratarelli, M. E., \& Browne, B. L. (2002). Confirmatory factor analysis of internet use and addiction. Psychology and Behavior, 5(1), 53-64.

Pratt, M. G., \& Foreman, P. O. (2000). Classifying managerial responses to multiple organizational identities. The Academy of Management Review, 25(1), 18-42.

Rogers, P., \& Blenko, M. (2006, February). Who has the D? How clear decision roles enhance organizational performance. Harvard Business Review, 84(1), 52-61.

Rosenbusch, N., Rauch, A., \& Bausch, A. (2013). The mediating role of entrepreneurial orientation in the task environment-performance relationship: A meta-analysis. Journal of Management, 39(3), 633-659.

Rusjan, B. (2005). Model for manufacturing strategic decision making. International Journal of Operations \& Production Management, 25(8), 740-761.

Samson, D., \& Terziovski, M. (1999). The relationship between total quality management practices and operational performance. Journal of Operations Management, 17(4), 393-409.

Schein, E. H. (1984). Culture as an environmental context for careers. Journal of Organizational Behavior, 5(1), 71-81.

Scherer, F. M. (1970). Industrial Market Structure and Economic Performance. Rand McNally: Chicago, IL.

Schneider, M., Schmidt, T. S., \& Hoffmann, V. H. (2010). Performance of renewable energy technologies under the CDM. Climate Policy, 10(1), 17-37. 
Schneider, S. C., \& Barsoux, J. L. (1997). Managing across cultures. Prentice Hall: London. Sekaran, U. (2003). Research methods for business: A skill building approach. New Delhi: John Wiley \& Sons.

Shi, W., Sun, J., \& Prescott, J. E. (2012). A temporal perspective of merger and acquisition and strategic alliance initiatives: Review and future direction. Journal of Management, 38(1), 164-209.

Shi, W. S., \& Prescott, J. E. (2008). The taxonomy of sequence of firm's M\&A and alliance behaviors: An exploratory analysis. Academy of Management Proceedings, 2008(1), 1-6.

Shil, P., \& Allada, V. (2007). Evaluating product plans using real options. The Engineering Economist, 52(3), 215-253.

Shook, C. L., Ketchen Jr., D. J., Hult, G. T. M., \& Kacmar, K. M. (2004). An assessment of the use of structural equation modeling in strategic management research. Strategic Management Journal, 25(4), 397-404.

Silva de Souza, G. H., Lima, N. C., Viegas Queiroz, J., Torres Penedo, A. S., Peçanha de Miranda Coelho, J. A., \& Silva Costa, A. C. (2013). Marketing approach of Brazilian wind energy sector. Journal of Technology Management \& Innovation, 8(4), 46-58.

Srinivasan, M. S. (2009, March). Rethinking corporate strategy - a consciousness perspective. Vilakshan: The XIMB Journal of Management, 6(1), 119-130.

Stuckey, M. M. (1990). Think small: Demassification is the key to fixing U.S. manufacturing. Industry Week, 239(18), 51.

Vargas, M. I. R. (2014). Determinant factors for small business to achieve innovation, high performance and competitiveness: Organizational learning and leadership style. Procedia - Social \& Behavioral Sciences, 169, 43-52.

Vickery, S. K. (1991). A theory of production competence revisited. Decision Sciences, 22(3), 635-643.

Vorhies, D. W., Morgan, R. E., \& Autry, C. W. (2009). Product-market strategy and the marketing capabilities of the firm: Impact on market effectiveness and cash flow performance. Strategic Management Journal, 30(12), 1310-1334.

Wernerfelt, B. (1984). A resource-based view of the firm: Summary. Strategic Management Journal, 5(2), 171-180.

Williams, C. T., \& Rains, J. (2007). Linking strategy to structure: The power of systematic organization design. Organization Development Journal, 25(2), 163-170.

Wright E. L. W., Juan, A. B., Adam, C., Pat, D., \& Gary, G. (2010, July). A scenario analysis of investment options for the Cuban power sector using the MARKAL model. Energy Policy, 38(7), 3342-3355.

Wu, P., Chen, T., \& Leung, K. (2011). Toward performance-based compensation: A study of the gaps between organizational practices and employee preferences with regard to compensation criteria in the state-owned sector in China. The International Journal of Human Resource Management, 22(9), 1986-2010.

Wulandari, H. (2014). Economy and technology as influential factors for digital piracy sustainability: An Indonesian case. Procedia-Social \& Behavioral Sciences, 164, 112117.

Zahra, S. A., Nash, S., \& Bickford, D. J. (1995). Transforming technological pioneering into competitive advantage. Academy of Management Perspectives, 9(1), 17-31. 